\title{
Ten minutes with Mr Peter Lees, CEO, Faculty of Medical Leadership and Management (FMLM)
}

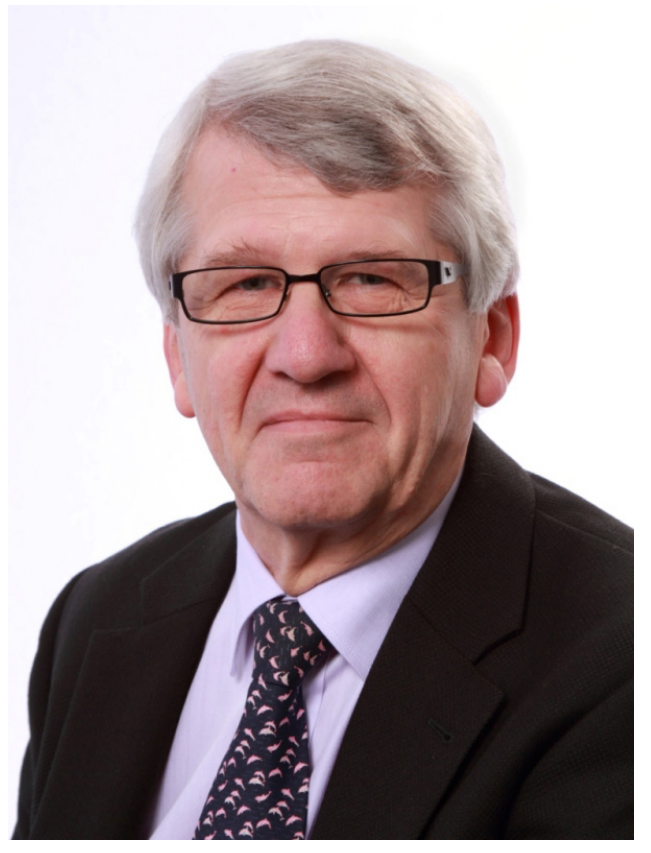

\section{FIRST AND FOREMOST, ARE THERE ANY KEY LEADERSHIP MESSAGES YOU WANT TO GET OUT TO OUR READERSHIP?}

This is clearly a highly complex situation.... and therefore requires a very different form of leadership from what we are used to as clinicians-accepting that managing complexity may be more familiar to primary care and public health colleagues. Much clinical training is geared to dealing with complicated problems and challenges, for which our expert role is helpful. That expertise allows us to be accomplished in defining a problem, selecting the best course of action and, within a defined range, predicting the likely outcome. But for complex problems, solutions are only obvious in hindsight and can only be found by groups of experts, not by a single person or even a small team. As leaders, we need to be careful that we do not use our tried and trusted expertiseof which we are justifiably proud-as being the way to tackle a complex problem. Answers will come from many different directions and positions, and we need to think inclusively, creating an environment that encourages different ideas for solutionsoften from sources with which we may be unfamiliar.

\section{TELL US A LITTLE BIT ABOUT YOUR LEADERSHIP ROLE AND HOW IT IS CHANGING AS A RESULT OF THE PANDEMIC?}

For several years now, we at the Faculty of Medical Leadership and Management (FMLM) have been building a professional body; setting standards, issuing guidance, developing our fellowship, running events and increasingly moving into supporting people and organisations under pressure. As that pressure has now increased dramatically, we are having to think hard about what we can offer that is most useful to people, now and into the future. Colleagues are overwhelmingly busy with planning and responding, so we are thinking too, about our next phase as a professional body, promoting and developing clinical leadership. We are also using our influence to advocate for supporting and caring for health and care leaders.

\section{Biography}

Peter Lees is the Chief Executive of the UK Faculty of Medical Leadership and Management (FMLM). In 2011, he led the establishment of FMLM which became an independent charity in January 2019. FMLM is now the second largest medical leadership organisation worldwide with over 2000 members. It jointly owns the journal BMJ Leader and the international leadership conference, Leaders in Healthcare. FMLM defined the first UK Leadership and management standards for medical professionals in 2015 and awards fellowships against those standards.

Previously, he combined a career in neurosurgery with senior roles in operational management and leadership development at Trust, regional and national levels and in global health. Formerly, he was Medical Director, Director of Workforce and Education and Director of Leadership at National Health Service South Central Strategic Health Authority. He was also Senior Lecturer in Neurosurgery at the University of Southampton from 1989 to 2011.

He is a Fellow of the Royal College of Surgeons of England, a Fellow of the Royal College of Physicians of London and a Senior Fellow of the FMLM. He is an Honorary Visiting Professor at Cass Business School, City, University of London and an Honorary Fellow of the Academy of Medical Educators.

\section{WHAT EVENTS IN YOUR PAST EXPERIENCE ARE MOST INFORMING YOUR LEADERSHIP IN THIS PANDEMIC?}

That is an interesting question. The nearest I came to this was the 2009 Influenza H1N1 ("swine flu") pandemic, when I was Medical Director at the NHS (National Health Service) South Central Strategic Health Authority (SHA). Then, the issues were the risks to healthcare workers, as the disease seemed disproportionately to affect the young. A major anxiety, beyond the tragedy of losing patients and colleagues, was how to sustain services when significant numbers of front-line staff were seriously ill or worse-very much a live issue again now.

I think I also draw heavily on my leadership experiences that have left me convinced by the 'science' encompassed in the anonymous quote: "for every complex problem there is a simple solution and it is wrong"; something that is sadly not understood by all, including some national commentators. Loud clarion calls for simplistic solutions are not infrequent, and merely make the job of leading more difficult than it needs to be. Also, I have always hated the tendency to blame whenever things go wrong. We need to make sure we can learn from judgements made by leaders and managers, especially when they seem to be 'wrong', just as we would advocate learning from a clinical incident without jumping to blame. As a profession, we have been very vocal about how the role of doctors places them under particular constraints, and so requires a sophisticated and curious approach to error and harm-the same logic should be applied to how we judge the actions and 'errors' of health and care leaders, especially in what all seem to agree is the most complex of times. I would go further-it will be negligent to not learn (globally) from this pandemic. After this is over, those who seek to blame and liberally apply the 'retrospectoscope' should reflect on their motives, and their impact on open and reasoned debate. 


\section{WHAT ARE YOU FINDING THE BIGGEST CHALLENGES?}

Avoiding rushing into doing something that makes me feel I am contributing but that is not actually helpful! It is also a challenge to persuade colleagues to accept support; to help them step back, reflect and develop their leadership skills in ways that complement them, while they are having to deliver day by day under great pressure.

\section{ANY PARTICULAR SURPRISES?}

Less surprised than pleased, but very impressed by the professionalism of the daily national briefings, seeing the united messaging from medical and scientific leaders, who I think have come across as credible, measured and honest.

\section{ARE YOU SEEING ANY BEHAVIOURS FROM COLLEAGUES THAT ENCOURAGE OR INSPIRE YOU?}

I have been impressed by the general desire to do good, with so many people seeming desperate to do something useful and valuable, resulting in very selfless behaviours from a huge number of people. And I have been massively impressed by the response from our colleagues in the National Medical Director's Clinical Fellows Scheme, a scheme that has given a fantastic return on investment from a great 10-year partnership between FMLM and first, Sir Bruce Keogh, and now Professor Steve Powis. Large numbers of alumni and current fellows are either going back to clinical roles, for example, at the Nightingale Hospital, or are working on the national response.

\section{HOW ARE YOU MAINTAINING KINDNESS AND COMPASSION?}

This is something I have believed in all my career, and for which my late mother was my exemplar! On occasions, I am sure I fall short but at the end of the day this is crucial. It has to be done through a concerted effort from everybody, which I think we are seeing. You cannot have enough kindness and, remember, its free! This must be sustained and we must not allow a minority-who may seek to divide us for their agenda to succeed-to drop us back into to what life was like before, with tribalism and other unhelpful behaviours. To respect the thousands who have sadly died, what a great legacy we could offer by becoming a more visibly compassionate, caring, understanding and less cynical society.

\section{ARE THERE ANY IDEAS OR READINGS THAT YOU FIND HELPFUL FOR INSPIRATION AND SUPPORT THAT YOU WOULD RECOMMEND TO OTHERS?}

There is a huge amount out there, and a huge need for support at this time, but it needs to be accessible to tired and busy people. We are circulating a very short weekly newsletter with opinion pieces and reflections from across the UK and from FMLM friends around the world. We have created a resource page on the FMLM website ${ }^{1}$ to signpost people to a range of articles and ideas-mostly very succinct. Within them, for me, there are a couple of particularly useful things.

The first is an $8 \mathrm{~min}$ video about the Cynefin framework, ${ }^{2}$ which is a way to see and understand the relationships between simple, complicated, complex and chaotic situations, and the different demands these make on leaders. We have been alerting FMLM members to this framework for a while because we find it incredibly useful, particularly at present because the pandemic as an event is complexity to its core. And we are seeing, from positive leadership behaviours in the pandemic, illustrations of what you should do in a complex situation; draw in multiple different expert perspectives (eg, in the Civil Contingencies Committee-commonly referred to as COBR—and the Scientific
Advisory Group for Emergencies-SAGE), decide and try out the best possible solution, then review the outcome and modify your response. All the while, you have to be constantly vigilant, and view decisions as if they are experiments that should be 'safe to fail'-a problem in a pandemic, but still true. Leaders cannot possibly get everything right all the time in such complexity, especially when events are moving so quickly and with so much accompanying anxiety.

The other piece of thinking that has resonated with me for some time now is David Rooke's work on Action Logics, ${ }^{34}$ a model that looks at different ways to respond to the world and therefore also to lead. His model categorises several different levels of leadership behaviour; of particular relevance to us at FMLM, thinking about doctors in leadership, are 'achievers'great at getting things done; 'experts'-vital to have but the expert mindset is often overfocused and narrow in a complex situation; and 'strategists'-essential to take the helicopter view and challenge orthodoxy. And, of course, all these ways of thinking add value and must be brought together and helped to work together through good leadership.

\section{WHAT ARE YOU LOOKING FOR FROM YOUR LEADERS?}

From all leaders-openness and honesty; realistic optimism; humanity, kindness and compassion; innovation and a drive for results.

From national leaders, an end to Punch and Judy politics that feed off blame and ridicule, and that offer simplistic solutions. And the first demonstration of a new order could be, at the right time, a mature process to review and reflect on what has gone well and what has not, to best prepare us for the next viruswhich may be even more malign!

Peter Lees, ${ }^{1}$ Anthony Robert Berendt ${ }^{2}$

${ }^{1}$ Faculty of Medical Leadership and Management, London, UK ${ }^{2}$ Oxford, UK

\section{Correspondence to}

Dr Anthony Robert Berendt, Oxford, UK; a.berendt@ntlworld.com

Twitter Anthony Robert Berendt @tony_berendt

Funding The authors have not declared a specific grant for this research from any funding agency in the public, commercial or not-for-profit sectors.

Competing interests None declared.

Patient consent for publication Not required.

Provenance and peer review Not commissioned; internally peer reviewed. Data availability statement No data are available.

(C) Author(s) (or their employer(s)) 2020. No commercial re-use. See rights and permissions. Published by BMJ.

\section{Check for updates}

To cite: Lees P, Berendt AR. BMJ Leader 2020;4:149-150.

Received 15 April 2020

Accepted 22 April 2020

Published Online First 30 April 2020

BMJ Leader 2020;4:149-150.

doi:10.1136/leader-2020-000265

\section{REFERENCES}

1 Faculty of Medical Leadership and Management. Support in the time of COVID 19 2020. Available: https://www.fmlm.ac.uk/support-in-the-time-of-covid-19

2 The Cynefin framework. Available: https://www.youtube.com/watch?v=N7oz366X0-8

3 Rooke D. Transformational leadership capabilities for medical leaders. BMJ Leader 2018;2:3-6.

4 Rooke D, Torbert W. "Seven transformations of leadership". Harvard Business Review 2005;83:66-76. 